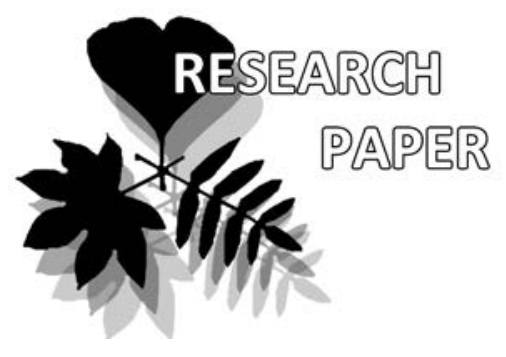

Nhlamulo N. Mashimbye ${ }^{1}$

e-mail: nhlamumashimbye@gmail.com

Annah N. Moteetee ${ }^{1}$

e-mail: amoteetee@uj.ac.za

Alexei A. Oskolski ${ }^{1,2 *}$

e-mail: aoskolski@uj.ac.za

${ }^{1}$ Department of Botany and Biotechnology, University of Johannesburg, South Africa

${ }^{2}$ Komarov Botanical Institute RAS, Saint Petersburg, Russia

* corresponding author

Manuscript received: 02.08 .2020

Review completed: 29.09.2020

Accepted for publication: 12.10.2020

Published online: 16.10 .2020

\section{Stem and leaf structure of Searsia erosa (Thunb.) Moffett (Anacardiaceae) with systematic, ecological and ethnobotanical implications}

\author{
Nhlamulo N. Mashimbye ${ }^{1}$, Annah N. Moteetee $^{1} \&$
} Alexei A. Oskolski ${ }^{1,2 *}$

\section{A B S T R A C T}

The anatomy of stems and leaves of the southern African evergreen shrub Searsia erosa (Anacardiaceae) was studied. This species shows the suite of typical traits of Anacardiaceae, such as the presence of secretory canals in the cortex, secondary phloem, wood rays and vascular bundle of leaf midrib, pericyclic fibres in nearly continuous bands, compound sieve plates on oblique walls, simple perforation plates, alternate intervessel pitting, and septate libriform fibres. Like other Searsia species, $S$. erosa has abundant sclereids in non-conducting secondary phloem, multicellular peltate glandular trichomes on leaf epidermis, short vessel elements and minute intervessel pits; two latter characters are thought to be diagnostic for this genus. Unlike Asian species of Searsia, S. erosa lacks marginal axial parenchyma as well as prismatic crystals in axial parenchyma and in libriform fibres, but it shows the helical thickenings on vessel walls. The presence of the last trait in a southern African species agrees with association of helical thickenings with the regions that experience water stress. The tangential expansion of secondary phloem in S. erosa and probably in other Searsia species is mainly performed by considerable increase in volume of its cells by their sclerification. Such a way of bark growth in girth is out of scope of bark anatomists. Searsia erosa is distinctive from other congeneric species in its hypostomatous leaves with abundant glandular trichomes on adaxial side. This condition demonstrates a labor division between the adaxial side with glandular trichomes that may contribute to leaf protection, and the stomata-bearing abaxial side providing the gas exchange. Unlike most members of Anacardiaceae, the secretory canals of $S$. erosa produce the oleoresin containing terpenoids (essential oils) and lipids, but lack polysaccharides. The abundance of glandular trichomes and secretory canals producing terpenoids is a presumable reason of the use of $S$. erosa in traditional medicine by the Basotho people.
\end{abstract}

K e y w o r d s : bark, wood, secondary phloem, sclereids, dilatation, hypostomaty, glandular trichomes, histochemistry, secretory canals, terpenoids, oleoresin, Basotho traditional medicine

\section{P E 3 Ю M E}

Машимбайе Н.Н., Мотити А., Оскольский А.А. Анатомия стебля и миста Searsia erosa (Thunb) Moffett (Anacardiaceae) в связи с систематикой, экологией и традиционным использованием этого виАа. Изучено анатомическое строение стебля и Аиста южноафриканского вечнозелёного кустарника Searsia erosa (Anacardiaceae). А^я этого виАа характерен набор признаков, типичных для других представителей семейства Anacardiaceae, таких как наличие секреторных каналов в кортексе, вторичной флоэме, мучах в Аревесине и в сосудистом пучке главной жилки миста, перициклические волокна в почти непрерывных полосах, сложные ситовидные пластинки на скошенных стенках, простые перфорационные пластинки, очередная межсосудистая поровость, септированные Аревесинные волокна. Подобно другим видам Searsia, S. erosa характеризуется об̆ильной склерификацией непроводящей вторичной флоэмы, наличием многоклеточных пельтатных железистых трихом на эпиАермисе Аиста, короткими члениками сосудов и мелкими межсосудистыми порами. Вероятно, Ава последних признака имеют диагностическое значение Аля рода. В отличие от азиатских вилов Searsia, y S. erosa отсутствует маргинальная осевая паренхима, а также призматические кристалмы в клетках осевой паренхимы и в Аревесинных волокнах, однако имеются спиральные утолщения на стенках сосудов. Наличие последнего признака у южноафриканского виАа согласуется с общей приуроченностью спиральных утолщений к регионам, испытываюшим водный стресс. Тангентальное расширение луба у S. erosa и, по-видимому, у Аругих видов Searsia, происходит главным образом за счет увеличения объема склерифицированных клеток. Этот способ увеличения периметра коры не привлекает Аостаточного внимания анатомов. S. erosa отличается от Аругих изученных виАов Searsia гипостоматными Аистьями с многочисленными железистыми трихомами на аАаксиальной стороне. Такое строение связано с разделением функщий межАу двумя сторонами миста: верхняя сторона, покрытая трихомами, обеспечивает зашиту миста, в то время как нижняя сторона специализирована на газообмене. В отличие от большинства представителей Anacardiaceae, в секреторных каналах $S$. erosa образуются маслосмолы, в составе которых присутствуют терпеноиды (эфирные масла) и АипиАы, но отсутствуют полисахариды. Обилие железистых трихомов и секреторных каналов, продуцирующих терпеноиды, может быть причиной использования $S$. erosa в традиционной медицине басуто.

КАючевые слова: кора, Аревесина, вторичная флоэма, склереиды, Аилатация, гипостомия, железистые трихомы, гистохимия, секреторные каналы, терпеноиды, традиционная медицина басуто 
Searsia erosa (Thunb.) Moffett is an evergreen shrub or multi-stemmed tree up to about $4 \mathrm{~m}$ in height with compound trifoliolate leaves. This species is distributed in the Northern Cape and the Free State Provinces of South Africa, as well as in Lesotho (Moteetee \& Van Wyk 2011). Leaves of Searsia erosa bear conspicuous sticky long and narrow leaflets, which are leathery in texture, and have a prominent midrib; its specific name 'erosa' is for the toothed leaf margins (Moffett 1994). These leaves have a strong turpentine resinous aroma when crushed, suggesting the presence of essential oils.

Searsia erosa is used in traditional medicine by the Basotho people for the treatment of a wide range of illnesses. These people are a southern African ethnic group found mostly in Lesotho and the Free State Province of South Africa, with a strong history with regard to the utilisation of medicinal plants (Moteetee et al. 2019). In both these countries, traditional medicine plays an important role in the health care and well-being of the rural population (Mugomeri et al. 2014, Shale et al. 1999, Buwa \& Van Staden 2006). The therapeutic properties of Searsia erosa are not widely-known outside the Basotho culture due to the confined geographical range of this species.

The genus Searsia, belonging to the sumac family Anacardiaceae has a disjunctive geographical range. The majority of its 120 species occur in Africa with the highest diversity in southern Africa, whereas three species are distributed along the eastern Himalayas in eastern Asia, and sparsely in NE India, Bhutan, SW China, and N Myanmar (Moffett 2007, Yang et al. 2016). Searsia has long been treated as part of the genus Rhus L., but was segregated from the latter by Barkley (1942) and Moffett (2007) on the basis of a distinctive combination of morphological traits (ternate leaves and a mesocarp adherent to the endocarp at maturity). The molecular phylogenetic analyses confirmed the monophyly of Searsia as well as its separated position from Rhus s.str. (Yi et al. 2007, Weeks et al. 2014, Yang et al. 2016).

The genus Searsia is very poorly explored by plant anatomists. The wood structure has been studied in two of the three Asian species of this genus namely, S. parviflora (Roxb.) F.A. Barkley (= Rhus parvifolia Roxb.) and S. mysorensis (G. Don) Moffett (= Rhus mysorensis G. Don), (Gupta \& Agarwal 2008), and also in two African species S. chirindensis (Baker f.) Moffett (= Rhus chirindensis Baker f.) and S. lancea (L. f.) F.A. Barkley (= Rhus lancea L. f.) (Kromhout 1975). Bark structure of several southern African species, i.e. S. batophylla (Codd) Moffett (= Rhus batophylla Codd), S. chirindensis (= Rhus chirindensis), S. gueinzii (Sond.) F.A. Barkley (= Rhus gueinzii Sond.), S. lancea (= Rhus lancea), S. leptodictya (Diels) T.S. Ti, A.J. Mill. \& J. Wen (= Rhus leptodictya Diels), S. natalensis (Bernh. ex Krauss) F.A. Barkley (= Rhus natalensis Bern. ex Krauss), S. pendulina (Jacq.) Moffett (= Rhus pendulina Jacq.), S. pyroides (Burch.) Moffett (= Rhus pyroides Burch.), S. rehmanniana (Engl.) Moffett (= Rhus rehmanniana Moffett), S. undulata (Jacq.) T.S. Ti, A.J. Mill. \& J. Wen (= Rhus undulata Jacq.) has been described by Ramovha (1997). The leaf anatomical data have been reported by Jordaan \& Kruger (1992) for S. burchellii (Sond. ex Engl.) Moffett (= Rhus burchellii Sond. ex Engl.). Apart from that, some data on structure of young stem and leaf of $S$. glutinosa (Hochst. ex A. Rich) Moffett has been reported by Madani \& Farouk (2019). In the present study, we describe the wood, bark and leaf structure of Searsia erosa combined with histochemical examination of some substances in its tissues in order to elucidate the taxonomic value and ecological significance of selected traits within this plant lineage as well as the structural background of traditional uses of this plant.

The purpose of the present study is to investigate the anatomical structure of stems and leaves of Searsia erosa, the plant organs used in the Basotho medicine. It was carried out as a part of pharmacognostic and phytochemical research of this species in order to find a scientific rationale for its traditional use. At the same time, the data on structure of vegetative organs of Searsia erosa are of great interest for systematics and ecology of the genus Searsia F.A. Barkley.

\section{MATERIAL AND METHODS}

Wood, bark and leaf sample of Searsia erosa was collected by L. Moteetee and the second author at Cholotsa Hill, Lekokoaneng in Berea District, Lesotho. The branch tips with leaves as well as the fragments of stems of $3 \mathrm{~cm}$ in diameters covered by mature bark with prominent periderm were fixed in $70 \%$ ethanol. Herbarium voucher (A. Moteetee and L. Moteetee \# 34) is deposited in JRAU. Fresh materials for histochemical studies were collected from the same locality.

Transverse, radial, and tangential sections of bark and wood from mature stem portions as well as transverse sections of juvenile stems were made using a freezing microtome (Ernst Leiz GMBH, Wetzlar, Germany), stained with a 1:1 alcian blue/safranin mixture, and mounted in Euparal. Wood macerations were made using Jeffrey's solution (Johansen 1940). Descriptive terminology follows recommendations of the IAWA Committee (1989) for wood structure, and Angyalossy et al. (2016) for bark.

The leaf fragments were embedded in glycol methacrylate (GMA) according to a modification of the Feder \& O’Brien (1968) method. Transverse sections of about $1 \mu \mathrm{m}$ thick were cut by using a Porter Blum MT-1 ultramicrotome and stained with Schiff - toluidine blue method before being mounted in Entellan.

Fresh leaves, branch tips and portions of mature bark, without fixation, were used for histochemical analysis. Free hand cross sections from stems, bark, and from the middle portion of leaflets were subjected to the following reagents/ tests: Vanilin-HCl (Gardner 1975) and ferric chloride (Johansen 1940) for tannins, Nadi reagent (David \& Carde 1964) for essential oils and other terpenoids; ruthenium red (Retamales \& Scharaschkin 2014) for non-cellulosic polysaccharides (including mucilage, pectins, gums etc.), and Sudan IV (Johansen 1940) for lipids (including suberin). For each procedure employed on the samples, control samples, slides without any treatment (blanks), were also mounted.

Light microscopic observations were performed with Olympus CX41 microscope; digital images and measurements were taken with an Olympus Stream Essentials 2.3.3 program.

The wood structure and the surface of dried leaves were investigated by scanning electron microscopy (SEM, 
TESCAN, soft - VegaTS) at the The Central Analytical Facility of the Faculty of Science, University of Johannesburg (Spectrum). Samples for SEM observations were mounted on aluminum stubs with double-sided carbon tape and coated with gold.

\section{RES U LTS \\ Bark anatomy}

The epidermis on young stems is composed of a single layer of more or less isodiametric rectangular (occasionally cone- or dome-like) cells with thin inner walls and thicker outer walls covered by thin cuticle (Fig. 1A, B). The majority of epidermal cells contain dark tannin deposits (positive vanilin- $\mathrm{HCl}$ and ferric chloride tests). Scarce peltate glandular trichomes were found on stem epidermis.

The cortex is very narrow (up to 3-5(8) cells in width), composed of 2-3 layers of lamellar collenchyma and 1-5 layers of parenchyma (Fig. 1A). The cells of cortical tissues are of $10-20 \mu \mathrm{m}$ in tangential size. Brown tannin deposits occur in cortical collenchyma cells. No crystals found in the cells of cortical collenchyma and parenchyma. Pericyclic fibres thick-walled (commonly with lamellar gelatinous walls), in broad (5-7 cells in width) arcs near secretory canals forming nearly continuous band interrupted only by narrow (2-4-seriate) medullary rays. Secretory canals are in the phloem parts of conductive bundles. The canal lumina are commonly 40-65 $\mu \mathrm{m}$ in tangential size (Fig. 1A, B). Their epithelial cells and the contents of canal lumina show positive reactions with Nadi reagent (violet staining) and with Sudan IV suggesting the presence of terpenoids and lipids, and negative reactions with ruthenium red indicating the lack of polysaccharides.

Mature bark non-peeling, brittle, with shallow fissured surface. The initiation of first-formed periderm is in the sub-epidermal layer of cells (Fig. 1B). Phellem is composed of 4-7 layers of isodiametric to somewhat radially-flattened or radially-elongated thin-walled cells. The phelloderm comprises 8-12 layers of radially flattened, thin- to moderately thick-walled cells, occasionally also very thick-walled cells (Fig. 1D). Some phelloderm cells contain brown tannin deposits (positive vanilin- $\mathrm{HCl}$ and ferric chloride tests). No crystalliferous cells were found in periderm. Subsequent periderms were not found (Fig. 1D, E).

Sieve tubes members 11-19 $\mu \mathrm{m}$ wide, and $424 \mu \mathrm{m}$ (277-606 $\mu \mathrm{m})$ long. Sieve tubes are in radial groups or clusters of 4-9 (Fig. 1G), while sieve plates are composed of 2-4 sieve areas located on vertical or slightly oblique cross walls (Fig. 1C). Axial parenchyma associated with conductive elements in strands of 4-10 cells, which are 10-22 $\mu \mathrm{m}$ in tangential size. No crystalliferous cells found in conducting secondary phloem. Axial secretory canals are scattered throughout the secondary phloem (Fig. 1D). They are lined by a single layer of $20-60 \mu \mathrm{m}$ in tangential size. 2-4-seriate parenchyma sheaths are present near the secretory canals. Epithelial cells and the contents of lumina of secretory canals show positive reactions with Nadi reagent (violet staining) and with Sudan IV suggesting the presence of terpenoids and lipids, and negative reactions with ruthenium red indicating the lack of polysaccharides.
The transition from conducting to non-conducting secondary phloem is sharp, marked by partial obliteration of sieve tubes, tangential stretching of secretory canals, and sclerification of some axial parenchyma cells (Fig. 1D). Sclereids are isodiametric, tangentially stretched and/or vertically elongated cells of $40-65 \mu \mathrm{m}$ in tangential size, with thick to very thick (occasionally lamellate) walls, arranged into large clusters, which are extended in the outer regions of non-conductive secondary phloem (Fig. 1F, G). Large prismatic crystals occur in some sclereids as well as in axial parenchyma strands adjacent to the sclereid clusters. Nonsclerified axial parenchyma cells in collapsed secondary phloem are mostly non-dilated, occasionally tangentially stretched and, rarely, in short tangential strands of 2-3 cells.

Secondary phloem rays are uniseriate and 2-3 seriate (Fig. 1H), composed of square and upright cells (the latter are mostly in uniseriate portions). Radial secretory canals not found. Some rays in non-conducting secondary phloem show weak dilatation by tangential stretching of rays cells, but the majority of rays are non-dilated (Fig. 1D, I). Sclerified cells occur in the rays of collapsed secondary phloem. Prismatic crystals rarely occur in ray cells (Fig. 1I).

\section{Wood anatomy}

Growth rings are distinct, marked by 3-6 rows of radially flattened fibres (Fig. 2A). Wood is diffuse-porous, occasionally semi-ring-porous. The vessels are rounded in outline, medium in diameter (average tangential size $70.2 \mu \mathrm{m}$, range 36-96 $\mu \mathrm{m}$ ) and few in number (average frequency 38.5 per $\mathrm{mm}^{2}$ ). Vessels are solitary and in radial multiples or in small clusters of 2-9. Vessel elements are $260 \mu \mathrm{m}$ (143$355 \mu \mathrm{m})$ long. Perforation plates are simple (Fig. 2C, D). Intervessel pitting alternate, pitts minute, $2-4 \mu \mathrm{m}$ in vertical size, circular to oval in shape, with rounded borders (Fig. 2B, E) and slit-like apertures in narrow (occasionally coalescent) grooves (Fig. 2F). Spherical warts occur in chambers of some intervessel pits (Fig. 2E). Vessel-ray pits are larger than intervessel pits, which are oval to horizontally elongated (scalariform) in outline, simple with reduced borders (Fig. 2B). Helical thickenings occur on the wall of some vessel elements (Fig. 2D). No tyloses were found.

Fibres are libriform, septate, thin- to thick-walled, with small simple pits on radial walls (Fig. 2B, C). Fibre length is $545 \mu \mathrm{m}(356-778 \mu \mathrm{m})$.

Axial parenchyma is scanty paratracheal, in solitary or an incomplete sheet around the vessels, with 3-6 cells per strand. No crystals found in axial parenchyma cells.

Rays 4.9-7.3 per mm, uni- and 2-3 seriate, occasionally 4-5-seriate, with radial canals (Fig. 2B). Ray height up to $0.65 \mathrm{~mm}$. All rays are heterogeneous, composed of procumbent, square and upright cells mixed throughout (Fig. 2C). Radial canals in few wide rays of 5 -seriate. Prismatic crystals in non-chambered upright and square ray cells (Fig. 2C).

\section{Leaf anatomy}

Leaf blade is dorsiventral, 230-320 $\mu \mathrm{m}$ thick (Fig. 3A). Epidermis in mostly uniseriate, but some cells of abaxial epidermis undergo periclinal divisions forming small biand triseriate patches. Epidermal cells with evenly thin walls, with cuticle of ca. $1 \mu \mathrm{m}$ thick on their outer wall, 

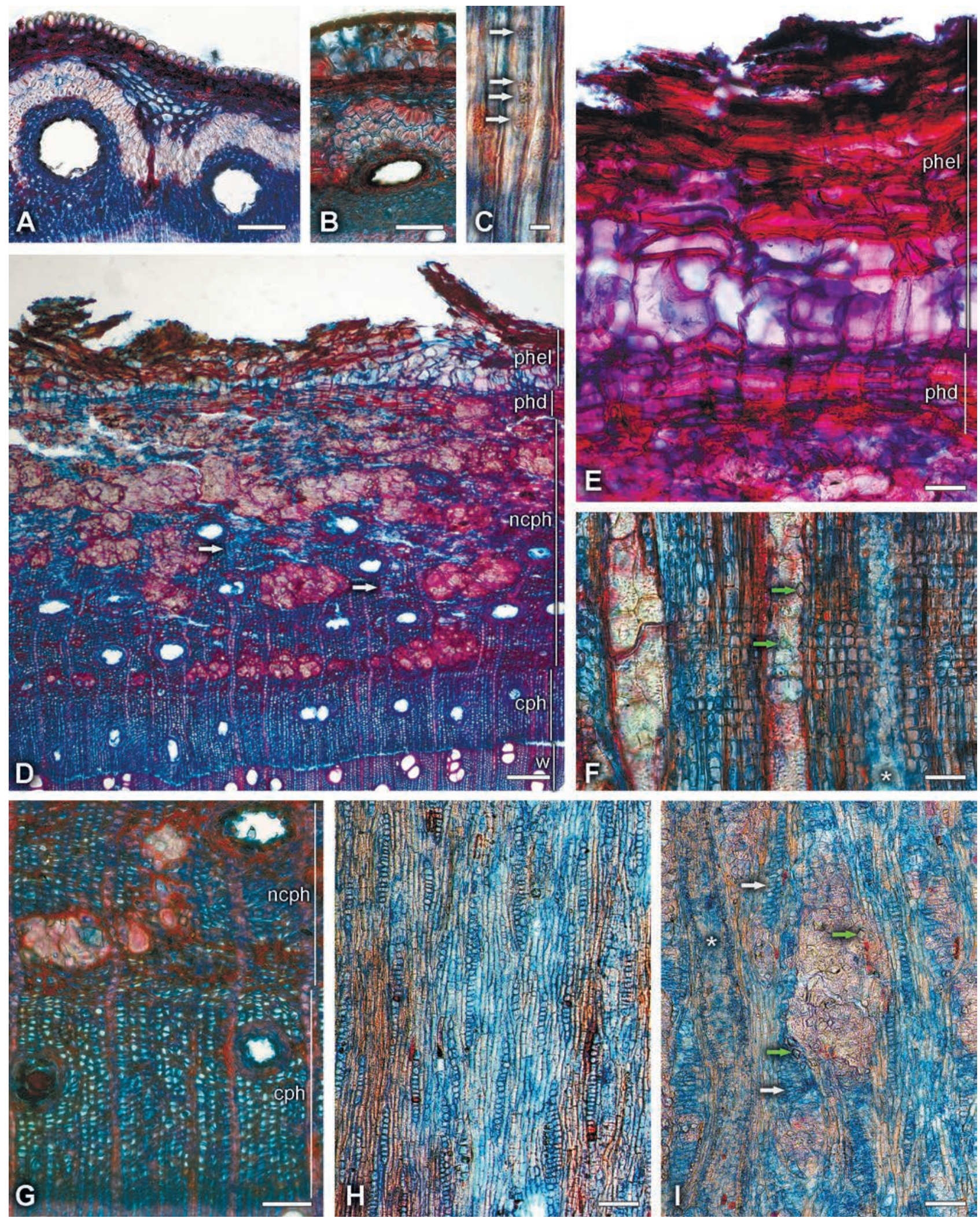
occasionally contain dark tannin deposits (positive vanilin- $\mathrm{HCl}$ and ferric chloride tests). Cells of adaxial epidermis are rounded, isodiametric to flattened in transverse sections, $12-16 \mu \mathrm{m}$ in tangential size, with straight to slightly curved anticlinal walls, bearing cuticle with striate microsculpture (Fig. 3C, E). Cells of abaxial epidermis rounded to polygonal, isodiametric to somewhat upright in transverse section, $7-14 \mu \mathrm{m}$ in tangential size, with curved to wavy anticlinal walls, bearing smooth cuticle (Fig. 3D, F). The palisade mesophyll consists of one or two layers of long upright cells (height/width ratio 6 to 13) (up to 7). The spongy mesophyll is in 3-5 layers of mostly upright (occasionally isodiametric) cells with large intercellular spaces inbetween (Fig. 3A, B).

Midrib (Fig. 3B) contains single large collateral vascular bundle accompanied with 4-5- seriate zone of annular to angular collenchyma on its adaxial side, and with 2-3-seriate zone of parenchyma on its abaxial side. Prismatic crystals occur in some collenchyma cells. The epidermis covering midrib on both its sides is distinctive from it from adjacent portions of lamina in having dome-like to bottle-like cells with thick outer walls. The vascular bundle in midrib consists of tangentially extended phloem and xylem zones, extended biseriate layer of sclereids on abaxial side, and a cluster of sclereids on adaxial side. Two large secretory canals (20-45 $\mu \mathrm{m}$ in diameter) found in phloem. Their epithelial cells and the contents of canal lumina show positive reactions with Nadi reagent (violet staining) and with Sudan IV suggesting the presence of terpenoids and lipids, and negative reactions with ruthenium red indicating the lack of polysaccharides. The vascular bundle is sheathed by one or two lavers of parenchymatous cells with dark tannin deposits (positive vanillin- $\mathrm{HCl}$ and ferric chloride tests). The tannins also found in solitary parenchyma cells located in phloem and xylem.
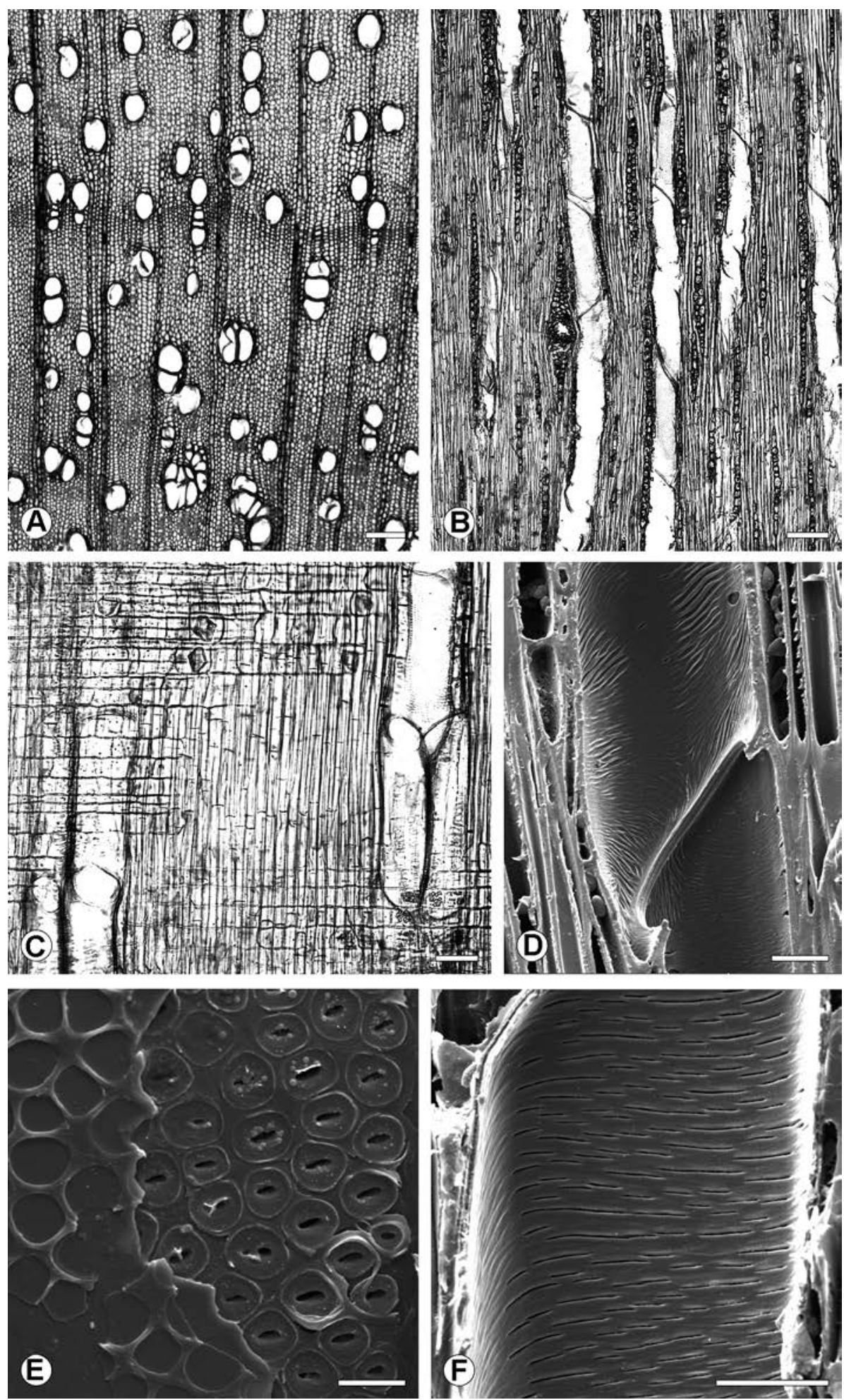

Figure 2 Wood structure of Searsia erosa: (A) distinct growth ring vessels solitary, and radial multiples and clusters of 2-9 (LM, TS); (B) alternate intervessel pitting, uni- and biseriate rays, radial secretory canal (LM, TLS); (C) vessel elements with simple perforation plates, septate fibers, oval to scalariform vessel-ray pits with reduced borders, septate libriform fibers, procumbent, square and upright ray cells mixed throughout, prismatic crystals in non-chambered ray cells (LM, RLS); (D) simple perforation plate, helical thickenings on vessel wall, scanning electron microscopy (SEM) (RLS); (E) minute intervessel pits in alternate arrangement, spherical warts in chambers of some pits (SEM, TLS); (F) solitary and coalescent narrow grooves with apertures of intervessel pits on inner vessel wall (SEM, TLS). Scale bars $=100 \mu \mathrm{m}(\mathrm{A}, \mathrm{B}), 50 \mu \mathrm{m}(\mathrm{C}), 20 \mu \mathrm{m}$ (D, F), $5 \mu \mathrm{m}(\mathrm{E})$. 

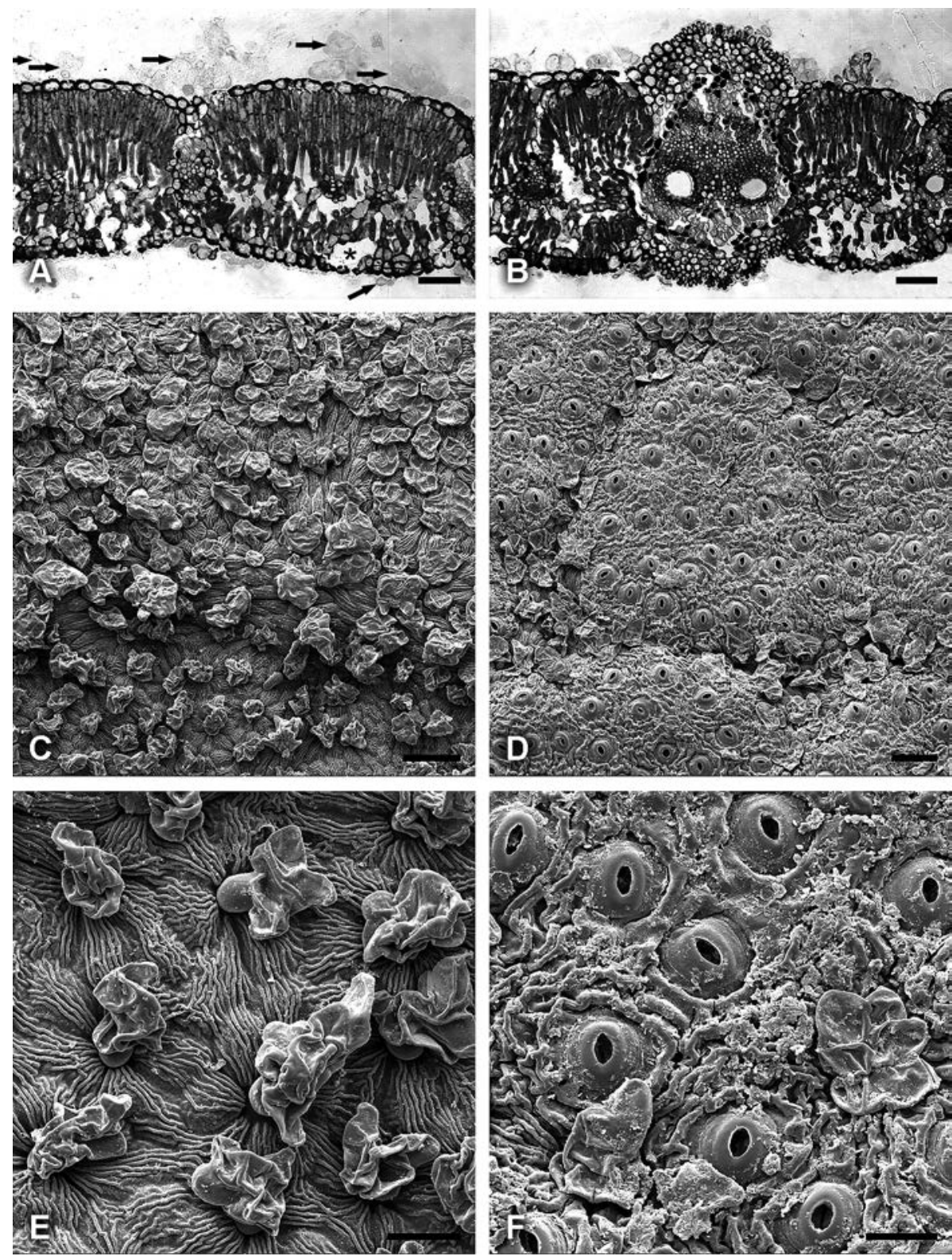

Figure 3 Leaf structure of Searsia erosa: (A) dorsiventral leaf lamina, abundant peltate trichomes on adaxial epidermis (black arrows), periclinal divisions in abaxial epidermal cells (arrowhead), stomatal chamber (asterisk) (LM, TS); (B) leaf midrib with single large collateral vascular bundle accompanied with zone of annular to angular collenchyma on its adaxial side, zone of parenchyma on its abaxial side, sheath of parenchyma cells with dark tannin deposits, epidermis on both sides domelike to bottle-like cells with thick outer walls, and two large secretory canals in phloem part of vascular bundle (LM, TS); (C) adaxial epidermis with numerous peltate glandular trichomes and lacking stomata (SEM); (D) abaxial epidermis with numerous stomata and few peltate glandular trichomes confined to vein grooves (SEM); (E) cells of adaxial epidermis with straight to slightly curved anticlinal walls, cuticle with striate microsculpture (SEM); (F) cells of abaxial epidermis with curved to wavy anticlinal walls, anomocytic stomata (SEM). Scale bars $=50 \mu \mathrm{m}(\mathrm{A}, \mathrm{B}, \mathrm{C}, \mathrm{D}), 20 \mu \mathrm{m}(\mathrm{E}, \mathrm{F})$

(Fig. 3C), whereas fewer ones $\left(112-122\right.$ per $\left.\mathrm{mm}^{2}\right)$ are confined to vein grooves on abaxial epidermis (Fig. 3D). The walls of basal and stalk cells of these trichomes are suberized (positive Sudan IV test). The head cells contain essential oils indicated by blue staining with Nadi reagent.

\section{I S C U S S I O N}

A suite of bark features (including pericyclic fibres in nearly continuous bands, the presence of secretory canals in the cortex and secondary phloem, compound sieve plates on oblique walls, axial parenchyma of secondary phloem in conspicuous tangential bands, and the occurrence of prismatic crystals in axial parenchyma cells) found in Searsia erosa, is typical for other genera of Anacardiaceae whose bark structure has been explored to date (Metcalfe \& Chalk 1950, Zahur 1959, Ellis 1974, Roth 1981, Ramovha 1997, Schweingruber et al. 2011, 2019, Eremin \& Kopanina 2012, Crivellaro \& Schweingruber 2013, Madani \& Farouk 2019). Among seven African species of Searsia examined by Ramovha (1997), $S$. erosa shows the greatest similarity to $S$. rehmanniana in its bark structure sharing the lack of dilatation meristem, the presence of sclereids in non-conducting secondary phloem, and the absence of tangential bands of sclereids in phelloderm, but it is distinctive from the latter species in the presence of prismatic crystals in sclereids.

Typical pattern of dilatation, such as tangential stretching of

and abaxial sclereid clusters, and their sheaths are associated with adaxial and abaxial extensions. Secretory canals lack in secondary and tertiary vascular bundles (Fig. 3A).

Stomata are anomocytic, scattered only on abaxial epidermis (325-338 per $\mathrm{mm}^{2}$ ), situated mostly at the level of the outer epidermal cell wall (Fig. 3A, D, F).

Peltate glandular trichomes consist of small basal cell (8-12 $\mu \mathrm{m}$ in tangential size) sunken between larger epidermal cells, spherical stalk cells $(10-14 \mu \mathrm{m}$ in diameter) and 4-8 head cells (Fig. 3A). Abundant trichomes (422438 per $\mathrm{mm}^{2}$ ) evenly scattered on adaxial epidermis thin-walled axial parenchyma and ray cells, is poorly expressed in non-conducting secondary phloem in Searsia erosa. Ramovha (1997) even described this condition as "the absence of dilatation tissue", that is considered by him as a taxonomically important trait for the genera Searsia and Smodingium. He also noted that "the secretory ducts are the sole site of dilatation in these two genera" (Ramovha 1997, p. 93). Our observations on Searsia erosa suggest, however, that the tangential expansion of outer regions of its bark is mainly performed by the considerable increase in volume of axial parenchyma cells in the course of their sclerification. This 
effect must also be significant in other Searsia species as well as in Smodingium argutum sharing abundant sclerenchyma in their non-conducting secondary phloem (Ramovha 1997). The predominance of the considerable increase in the cell walls thickness over the dilatation of thin-walled cells occurs also in mature bark of other trees having abundant sclerenchyma, as e.g. in some Populus species (Eremin \& Kopanina 2012). Such a way of bark transformation in the course of its growth in girth is, however, out of scope of bark anatomists; it has not been mentioned even in the recent comprehensive review of microscopic bark features (Angyalossy et al. 2016). Comparative assessment of the contributions of sclerification and dilatation into tangential expansion of bark in different plant taxa would be of great interest for plant anatomy.

Such suite of wood traits as exclusively simple perforation plates, alternate intervessel pitting, septate libriform fibers, paratracheal axial parenchyma, heterocellular rays occasionally containing radial secretory canals, and the presence of prismatic crystals in ray cells, found in Searsia erosa, is typical of most genera of the family Anacardiaceae examined to date (Meltcalfe \& Chalk 1950, Mitchell \& Daly 2015, Dong \& Baas 1993, Gupta \& Agarwal 2008, Crivellaro \& Schweingruber 2013, InsideWood, 2004-onwards). At the same time, the species under study shows shorter vessel elements (average length $260 \mu \mathrm{m}$ ) and smaller intervessel pits (2-4 $\mu \mathrm{m}$ in vertical size) than the majority of Anacardiaceae members. Short vessel elements and minute intervessel pits has also been reported, however, in Searsia parviflora and $S$. mysorensis, two of three Asian species of this genus (Gupta \& Agarwal 2008). The similarity between S. erosa and these two species confirms close affinity between African and eastern Asian lineages of Searsia revealed by molecular phylogenetics (Yang et al. 2016). Our data also suggest that the combination of those quantitative wood traits can be diagnostic for the genus Searsia, supporting its segregation from Rhus (Moffett 2007), the genus showing longer vessel elements and large intervessel pits (Dong \& Baas 1993, Gupta \& Agarwal 2008). A comprehensive wood anatomical study of African Searsia species is required, however, to test diagnostic value of these traits.

Unlike Asian species of Searsia, however, Searsia erosa lacks marginal axial parenchyma as well as prismatic crystals in axial parenchyma and in fibers, but it shows the helical thickenings in vessel elements. The last trait is found in several lineages of Anacardiaceae, i.e. in the clade comprising Rhus, Toxicodendron, Cotinus, Pistacia and Haplorbus; in Schinus and Lithraea as well as in Tapirira and also in Smodingium (InsideWood 2004-onwards, Weeks et al. 2014, Muellner-Riehl et al. 2016, Silva-Luz et al. 2019). Our data showed that helical thickenings are gained also in the African Searsia. Among modern angiosperms, this feature is most common in woods of temperate regions, but is rare in the tropics (Wheeler et al. 2007). As noted by Carlquist (2001), helical thickenings are associated with regions that experience water stress created by drought or freezing. He suggested that this feature might diminish in some way the danger of cavitation, aid in refilling of vessels, or increasing vessel wall strength. The occurrence of helical thickenings in wood of a species from southern Africa coupled with its lack in its relatives from tropical Asia is in good agreement with this ecological trend. A comprehensive wood anatomical study of African Searsia species is required, however, to test this hypothesis and to evaluate diagnostic value of their wood traits as well.

Sharing most leaf traits with Searsia burchellii (Jordaan \& Kruger 1992) and S. glutinosa (Madani \& Farouk 2019), S. erosa is distinctive from both these species in its hypostomatous leaves (with stomata only on abaxial side) and very abundant glandular trichomes on adaxial side. Besides that, $S$. burchellii differs from $S$. erosa and $S$. glutinosa in common occurrence of tannins in its epidermal cells (Jordaan \& Kruger 1992), whereas $S$. glutinosa is distinctive from two former species in having unicellular non-glandular trichomes along with multicellular glandular ones (Madani \& Farouk 2019). Our data show, therefore, that the distribution of stomata between leaf sides can vary significantly within the genus Searsia. The amphistomaty (i.e. the presence of stomata on both leaf sides), the condition reported in S. burchellii and $S$. glutinosa, provides an advantage over hypostomaty in gasexchange between mesophyll and atmosphere that allows for greater photosynthetic productivity (Drake et al. 2019). This feature is shown as adaptive for plants of open vegetation with high light environment (Jordan et al. 2014, Muir 2018). At the same time, the higher risk of desiccation due to increased transpiration surface, lower ability to buffer fluctuations of water potential while stomata are open, and greater susceptibility for entry of foliar pathogens through stomata in the upper epidermis are considered as the costs of amphistomatous leaf morphology (McKown et al. 2014, Drake et al. 2019). Due to these costs, the amphistomaty is a much less common condition within angiosperms than hypostomaty.

As all three species (S. erosa, S. burchellii and S. glutinosa) inhabit sunny and dry habitats, the difference in their stomatal distribution is unlikely related to the variations in light and water availability. More likely, it must be explained in terms of trade-off between carbon gain and leaf protection against fungal pathogens, herbivores or abiotic factors, as it has been shown for the intraspecific variation of leaf traits in Populus trichocarpa (McKown et al. 2014). Leaves of S. erosa demonstrate a prominent labour division between the abaxial side covered with abundant glandular trichomes that may contribute to resistance against insect pests, microbial pathogens, and/or atmospheric ozon stress (Wagner 1991, Li et al. 2018), and the stomata-bearing adaxial side providing the gas exchange between mesophyll and environment. Searsia burchellii and $S$. glutinosa have seemingly less protected leaves with better uptake of carbon dioxide than $S$. erosa. The scarcity of glandular trichomes in $S$. burchellii is thought to be partially compensated by the abundance of tannin deposits in its epidermal cells that may also be involved in protection against reactive oxygen species, UV radiation and/or herbivory (Constabel et al. 2014). A comparative eco-physiological study of Searsia species is required to assess the influence of different environmental factors on interspecific variation of their stomata patterning and quantity of glandular trichomes. As the essential oils from some individuals of $S$. erosa show high antimicrobial activity (unpublished results), the abundance of glandular trichomes is thought to be one of preconditions for its use in traditional medicine. 
The occurrence of secretory canals in vegetative and reproductive organs is one of the most prominent features of the family Anacardiaceae (Metcalfe \& Chalk 1950, Pell et al. 2011). Their secretion in the majority of studied taxa is characterized as gum-resin, as it consists of both lipophylic substances (terpenoids, occasionally also lipids), and hydrophilic ones (polysaccharides). The presence of gum-resins has been reported in the secretory canals in Rhus glabra L. (Fahn \& Evert 1974), Toxicodendron pubescens Mill. (Vassilyev 2000), Semecarpus anacardium L. f. (Bhatt \& Mohan Ram 1992), Mangifera indica L. (Joel \& Fahn 1980), Spondias dulcis L. (Sant'Anna-Santo et al. 2006, Lacchia \& Guerreiro 2009), Tapirira guianensis Aubl. (Lacchia \& Guerreiro 2009), and in juvenile shoots of Anacardium occidentale L. (Nair et al. 1983). Unlike these taxa, the secretory canals in Lannea coromandelica presumably produce only gum, i.e. poysaccharide secretion (Venkaiah 1992), whereas Spondias mombin L. as well as flowers and fruits of Anacardium bumile Hance ex Engl. share the resin secretions containing only lipophylic substances (De Vasconcelos et al. 2016, Lacchia \& Guerreiro 2009). Our histochemical data suggest that the secretion of the canals found in cortex, secondary phloem and in leaf midribs of Searsia erosa also consists only of essential oils and lipids having no polysaccharide components. Such composition of secretion, that may be termed as oleoresin, is uncommon for the Anacardiaceae. The presence of numerous secretory canals producing the oleoresin can also make condition for traditional medicinal use of this plant species.

\section{CONCLUSIONS}

Searsea erosa shows overall similarity in structure of its stem and leaf to other Searsia examined to date. The comparison of our observations with other reported data on anatomy of this genus and other Anacardiaceae genera allow us to make the following conclusions:

1. The tangential expansion of outer regions of bark in S. erosa and probably in other Searsia species is mainly performed by the considerable increase in volume of axial parenchyma cells in the course of their sclerification. Such a way of bark transformation in the course of its growth in girth is out of scope of bark anatomists.

2. The combination of short vessel elements and minute intervessel pits can presumably be diagnostic for the genus Searsia.

3. The distribution of stomata between leaf sides (amphistomaty vs hypostomaty) as well as the abundace of glandular trichomes on the leaf epidermis can vary significantly within this genus Searsia. Leaves of S. erosa demonstrate a prominent labor division between the adaxial side covered with very abundant glandular trichomes that may contribute to resistance against insect pests, microbial pathogens, and/or atmospheric ozon stress, and the stomatabearing abaxial side providing the gas exchange between mesophyll and environment.

4. Unlike most members of Anacaridaceae studied to date, the secretory canals in cortex, secondary phloem and vascular bundles of leaf midrib produce oleoresin containing terpenoids (essential oils and lipids). No polysaccharides found in their secretion.
5. The secretion of terpenoids in abundant glandular trichomes on leaves and in secretory canals found in cortex, secondary phloem and leaf midribs of $S$. erosa is a presumable reason of the use of this plant in traditional medicine of Basotho people.

\section{ACKNOW LEDGEMENTS}

This work is based on the research supported in part by the National Research Foundation of South Africa (grant no. 93625 for A.M., and incentive grant No. 109531 for A.O.), and also by the Russian Foundation for Basic Research (grant no. 19-04-00714 for A.O.) and the Komarov Botanical Institute (institutional research Project No. AAAA-A19-119030190018-1). The authors acknowledge the University of Johannesburg for financial and logistical support.

\section{LITERAT URE CITED}

Angyalossy, V., M.R. Pace, R.F Evert, C.R. Marcati, A.A. Oskolski, T. Terrazas, E. Kotina, F. Lens, S.C. Mazzoni, G. Angeles, S.R. Machado, A. Crivellaro, K.S. Rao, L. Junikka, N. Nikolaeva \& P. Baas 2016. IAWA List of microscopic bark features. IAWA Journal 37(4):517-615.

Barkley, F.A. 1942. A key to the genera of the Anacardiaceae. American Midland Naturalist 28:465-474.

Bhatt, J.R. \& H.Y. Mohan Ram 1992. Development and ultrastructure of primary secretory ducts in the stem of Semecarpus anacardium (Anacardiaceae). LAWA Bulletin 13:173-185.

Buwa, L.V. \& J. Van Staden 2006. Antibacterial and antifungal activity of traditional medicinal plants used against venereal diseases in South Africa. Journal of Ethnopharmacology 103(1):139-142.

Constabel, C.P., K. Yoshida \& V. Walker 2014. Diverse ecological roles of plant tannins: Plant defence and beyond. In: Recent advances in polyphenol research (A. Romani, V. Lattanzio \& S. Quideau, eds), vol. 4, pp. 115-142, John Wiley \& Sons, Chichester, West Sussex, UK.

Crivellaro, A., \& F.H. Schweingruber 2013. Atlas of wood, bark and pith anatomy of Eastern Mediterranean trees and shrubs: with a special focus on Cyprus. Heidelberg, New York, Dordrecht, London: Springer.

David, R. \& J.P. Carde 1964. Coloration différentielle des inclusions lipidique et terpéniques des pseudophylles du pin maritime au moyen du réactif Nadi. Comptes rendus de l'Académie des Sciences, Paris 258(4):1338-1340.

De Vasconcelos, A.L., A.L. De Vasconcelos \& K.P. Randau 2016. Pharmacognostic characterization of Spondia mombin L. (Anacardiaceae). Pharmacognosy Journal 8(6):513-519.

Dong, Z. \& P. Baas 1993. Wood anatomy of trees and shrubs from China. V. Anacardiaceae. IAWA Journal 14(1):87-102.

Drake, P.L., H.J. de Boer, S.J. Schymanski \& E.J. Veneklaas 2019. Two sides to every leaf: water and $\mathrm{CO}_{2}$ transport in hypostomatous and amphistomatous leaves. New Phytologist 222:1179-1187.

Ellis, R.P. 1974. Smodingium dermatitis: the intercellular secretory canals of aerial axis and their relationship to toxicity. Bothalia 11(3):259-262.

Eremin, V.M. \& A.V. Kopanina 2012. Atlas of the bark anatomy of trees, shrubs and lianas of Sakhalin and the Kuril Islands. Poligrafika, Brest, 896 pp. (in Russian). [Еремин B.M., Копанина А.В. 2012. Атлас анатомии коры деревьев, 
кустарников и миан Сахалина и Курильских островов. Брест: Полиграфика. 896 с.].

Fahn, A. \& R.F. Evert 1974. Ultrastructure of secretory ducts of Rhus glabra L. American Journal of Botany 61:1-14.

Feder, N. \& T.P. O’Brien 1968. Plant micro-techniques: some principles and new methods. American Journal of Botany 55: 123-143.

Gardner, R.O. 1975. Vanillin-hydrochloric acid as a histochemical test for tannin. Stain Technology 50(5):315-317.

Gupta, G., \& M. Agarwal 2008. Wood anatomy of Anacardiaceae from India with special reference to the systematic position of Rhus. LAWA Journal 29(1):79-106.

IAWA Committee 1989. IAWA list of microscopic features for hardwood identification. IAWA Bulletin New Series 10: 219-332.

InsideWood. 2004-onwards. Published on the Internet. [accessed 2020 July 12]. http://insidewood.lib.ncsu.edu/ search. Last accessed 20.09.2020.

Johansen, D.A. 1940. Plant microtechnique. McGraw-Hill, New York

Jordaan, A. \& H. Kruger 1992. Leaf surface and anatomy of two xerophytic plants from southern Africa. South African Journal of Botany 58(3):133-138.

Jordan, G.J., R.J. Carpenter \& T.J. Brodribb 2014. Using fossil leaves as evidence for open vegetation. Palaeogeography, Palaeoclimatology, Palaeoecology 395:168-175.

Joel, D.M. \& A. Fahn 1980. Ultrastructure of resin ducts of Mangifera indica L. (Anacardiaceae). II. Resin secretion in the primary stem ducts. Annals of Botany 46:779-783.

Kromhout, C.P. 1975. 'n Sleutel vir die mikroskopiese uitkenning van die vernaamste inheemse houtsoorte van SuidAfrika. South African Department of Forestry Bulletin 50:124

Lacchia, A.P.S. \& S.M.C. Guerreiro 2009. Aspectos ultraestruturais dos canais secretores em órgãos vegetativos e reprodutivos de Anacardiaceae. Acta Botanica Brasilica 23(2):376-388.

Li, S., T. Tosens, P.C. Harley, Y.F. Jiang, A. Kanagendran, M. Grosberg, K. Jaamets \& U. Niinemets 2018. Glandular trichomes as a barrier against atmospheric oxidative stress: relationships with ozone uptake, leaf damage, and emission of LOX products across a diverse set of species. Plant, Cell and Environment 41(6):1263-1277.

Madani, I. \& A. Farouk 2019. Stem and leaf anatomy of Searsia glutinosa subsp abyssinica (synonym: Rhus abyssina) (Anacardiaceae) from Erkwit, Sudan. European Academic Research 6(11):6194-6199.

McKown, A.D., R.D. Guy, L. Quamme, J. Klápště, J. La Mantia, C.P. Constabel, Y.A. El-Kassaby, R.C. Hamelin, M. Zifkin \& M.S. Azam 2014. Association genetics, geography and ecophysiology link stomatal patterning in Populus trichocarpa with carbon gain and disease resistance trade-offs. Molecular Ecology 23:5771-5790.

Metcalfe, C.R. \& L. Chalk 1950. Anatomy of the dicotyledons, vol. 1. Clarendon Press, Oxford.

Moffett, R.O. 1994. Names of the southern African species of Rhus (Anacardiaceae) and their etymology. Bothalia 24(1):67-76.

Moffett, R.O. 2007. Name changes in the Old World Rhus and recognition of Searsia species (Anacardiaceae). Bothalia 37(2):165-175.
Moteetee, A. \& B-E. Van Wyk, B-E. 2011. The medicinal ethnobotany of Lesotho: a review. Bothalia 41(1):209-228.

Moteetee, A., R.O. Moffett \& L. Seleteng-Kose 2019. A review of the ethnobotany of the Basotho of Lesotho and the Free State Province in South Africa (South Sotho). South African Journal of Botany 122:21-56.

Muellner-Riehl, A.N., A. Weeks, J.W. Clayton, S. Buerki, L. Nauheimer, Y.-C. Chiang, S. Cody \& S.K. Pell 2016. Molecular phylogenetics and molecular clock dating of Sapindales based on plastid $r b c \mathrm{~L}$, atp $\mathrm{B}$ and $\operatorname{trn} \mathrm{L}-\operatorname{tr} n \mathrm{~F}$ DNA sequences. Taxon 65(5):1019-1036.

Mugomeri, E., P. Chatanga, S. Hlapisi \& L. Rahlao 2014. Phytochemical characterisation of selected herbal products in Lesotho. Lesotho Medical Association Journal 12(1): 38-46.

Muir, C.D. 2018. Light and growth form interact to shape stomatal ratio among British angiosperms. New Phytologist 218:242-252

Nair, G.M., K. Venkaiah \& J.J. Shah 1983. Ultrastructure of gumresin ducts in cashew (Anacardium occidentale). Annals of Botany 51:297-305.

Pell, S.K., J.D. Mitchell, A.J. Miller \& T.A. Lobova 2011. Anacardiaceae. In: Families and genera of vascular plants $X$. Flowering plants. Eudicots. Sapindales, Cucurbitales, Myrtaceae (K. Kubitzki, ed.), pp. 7-50, Springer, Heidelberg, Dordrecht, London, New York.

Ramovha, L.I. 1997. The taxonomic significance of bark structure in South African Anacardiaceae. Unpublished MSc dissertation. University of Pretoria. Pretoria.

Retamales, H. \& T. Scharaschkin 2014. A staining protocol for identifying secondary compounds in Myrtaceae. Applications in Plant Sciences 2(10):1400063.

Roth, I. 1981. Structural patterns of tropical barks. Borntraeger Gebrüder, Berlin, 609 pp.

Sant'Anna-Santo, B. F., M. Thadeo, R.M. Meira \& L. Ascensão 2006. Anatomia e histoquímica das estruturas secretoras do caule de Spondias dulcis Forst. F. (Anacardiaceae). (Anacardiaceae). Revista Árvore 30(3):481-489.

Shale, T.L., W.A. Stirk \& J. Van Staden 1999. Screening of medicinal plants used in Lesotho for anti-bacterial and anti-inflammatory activity. Journal of Ethnopharmacology 67(1):347-354

Silva-Luz, C.L., J.R. da Piran, J.D. Mitchell, D. Daly, N.V. Capelli, D. Demarco, S.K. Pell \& G.M. Plunkett 2019. Phylogeny of Schinus L. (Anacardiaceae) with a new infrageneric classification and insights into evolution of spinescence and floral traits. Molecular Phylogenetics and Evolution 133:302-351.

Schweingruber, F.H., A. Börner \& E-D. Schulze 2011. Atlas of stem anatomy in herbs, shrubs and trees, vol. 1. Springer, Heidelberg, New York, Dordrecht, London.

Schweingruber, F.H., P. Steiger \& A. Börner 2019. Bark anatomy of trees and shrubs in the temperate Northern Hemisphere. Springer.

Vassilyev, A.E. 2000. Quantitative ultrastructural data of secretory duct epithelial cells in Rhus toxicodendron. International Journal of Plant Sciences 161:615-630.

Venkaiah, K. 1992. Development, ultrastructure and secretion of gum ducts in Lannea coromandelica (Hout) Merrill (Anacardiaceae). Annals of Botany 69:449-457.

Wagner, G.J. 1991. Secreting glandular trichomes: more than just hairs. Plant Physiology 96:675-679. 
Weeks, A., F. Zapata, S.K. Pell, D.C. Daly, J. Mitchell \& P.V.A. Fine 2014. To move or evolve: contrasting patterns of intercontinental connectivity and climatic niche evolution in "Terebinthaceae" (Anacardiaceae and Burseraceae). Frontiers in Genetics 5:409.

Wheeler, E.A., P. Baas \& S. Rodgers 2007. Variations in dicot wood anatomy: a global analysis based on the InsideWood database. IAWA Journal 28:229-258.

Yang, Y., Y. Meng, J. Wen, H. Sun \& Z. Nie 2016. Phylogenetic analysis of Searsia (Anacardiaceae) from eastern
Asia and its biogeographic disjunction with its African relatives. South African Journal of Botany 106(1):129-136.

Yi, T., A.J. Miller \& W. Jun 2007. Phylogeny of Rhus (Anacardiaceae) based on sequences of nuclear Nia-i3 intron and chloroplast trnC-trnD. Systematic Botany 32(2):379-391.

Zahur, M.S. 1959. Comparative study of secondary phloem of 423 species of woody dicotyledons belonging to 85 families. Memoirs Cornell University Agricultural Experiment Station 358:1-160. 